\title{
ASPECTOS DO INSTITUTO DO DIVÓRCIO IMPOSITIVO: UMA ANÁLISE À LUZ DA PROTEÇÃO DOS DIREITOS DA PERSONALIDADE, NESTE INÍCIO DO SÉCULO XXI
}

\author{
Silvio Hideki Yamaguchi ${ }^{1}$
}

\section{RESUMO}

Visando ampliar o instituto do divórcio extrajudicial, tramita perante o Senado Federal proposta legislativa com o fim de incluir o divórcio impositivo entre uma das modalidades de divórcio extrajudicial. Assim, busca-se responder a problemática: é possível considerar o divórcio impositivo como um mecanismo de proteção do cônjuge interessado na dissolução do vínculo matrimonial, à luz dos direitos da personalidade? Tem-se como objetivo geral, analisar se o divórcio impositivo poderia ser considerado como instrumento de efetivação dos direitos da personalidade do cônjuge requerente. A pesquisa pautou-se na metodologia de revisão bibliográfica.

PALAVRAS-CHAVES: Divórcio extrajudicial; Divórcio impositivo; Direitos da personalidade; Autonomia da vontade. Direito de Família.

\section{ASPECTS OF THE INSTITUTE OF IMPOSIVE DIVORCE: AN ANALYSIS IN THE LIGHT OF THE PROTECTION OF PERSONALITY RIGHTS IN THIS BEGINNING OF THE 21ST CENTURY}

\section{ABSTRACT}

Aiming to expand the institute of extrajudicial divorce, a legislative proposal is being processed before the Federal Senate with the aim of including tax divorce as one of the modalities of extrajudicial divorce. Thus, the aim is to answer the problem: is it possible to consider tax divorce as a protection mechanism for the spouse interested in the dissolution of the matrimonial bond, in light of personality rights? The general objective is analyze whether the tax divorce could be considered as instrument for realization of the personality rights of requesting spouse. The research was based on the literature review methodology.

KEYWORDS: Extrajudicial divorce; Tax divorce; Personality rights; Autonomy of the will. Family right.

\section{INTRODUÇÃO}

O instituto do divórcio foi introduzido no ordenamento jurídico brasileiro por intermédio da Lei n ${ }^{\circ}$ 6.515/77, com a vigência da Emenda Constitucional n 9/77.

\footnotetext{
${ }^{1}$ Mestrando em Ciências Jurídicas pela Unicesumar; Pós-Graduado em Direito Civil pelo Instituto Damásio da Jesus; Pós-Graduado em Direito Notarial e Registral pela Unifamma; Pós-Graduado pela Escola da Magistratura do Paraná; Graduado em Direito pela Pontifícia Universidade Católica do Paraná; Juiz Estadual; E-mail: silvioshy@gmail.com.
} 
O divórcio no Brasil, só se institucionalizou da forma como se é conhecido contemporaneamente após 2010, em que se retirou os requisitos temporais ou a prévia necessidade de separação judicial, figurando como uma conquista social muito grande diante das legislações anteriores, conservadoras e patriarcais. A possibilidade do divórcio extrajudicial só se efetivou em 2007 e, até 2010, ainda exigia-se o cumprimento do requisito temporal para, só então, permitir o divórcio extrajudicial, requisito esse que, posteriormente com a Emenda Constitucional nº66/2010, também deixou de ser exigida.

O divórcio extrajudicial apresentou-se de suma importância no ordenamento jurídico brasileiro, ao desburocratizar e dar rapidez a dissolução dos vínculos matrimoniais quando há consenso dos cônjuges e não há filhos menores, incapazes ou nascituros decorrentes da relação de ambos, promovendo uma abertura institucional para que as demandas judiciais não sejam a única alternativa para promover o divórcio, evitando longas demoras e sofrimento psíquico desnecessário.

Considerando a importância que o divórcio extrajudicial exerce no Brasil, somado a defesa de que o divórcio seria um direto potestativo do cônjuge não interessado em prosseguir com o casamento, surgiu-se a proposta de inclusão de nova modalidade de divórcio extrajudicial, o divórcio impositivo, que se efetivaria em Cartório apenas com a vontade de um dos cônjuges em se divorciar. Tal proposta encontra-se tramitando no Senado, por meio do Projeto de Lei no 3.457 , de 2019.

Nesse cenário, o presente artigo visa responder a seguinte problemática: é possível considerar o divórcio impositivo como um mecanismo de proteção do cônjuge interessado na dissolução do vínculo matrimonial, à luz dos direitos da personalidade?

Assim, tem-se como objetivo geral, analisar se o divórcio impositivo poderia ser considerado como um instrumento de efetivação dos direitos da personalidade do cônjuge que tem interesse no divórcio, levando-se em consideração especial a autonomia da vontade e a liberdade afetiva. Como objetivos específicos, tem-se a análise: da evolução do divórcio no Brasil; da importância exercida pelo divórcio extrajudicial no ordenamento jurídico brasileiro; dos contornos jurídicos que envolvem o divórcio impositivo na contemporaneidade; e, por fim, do papel do divórcio impositivo em relação aos direitos da personalidade do cônjuge interessado na efetivação do divórcio.

Para tanto, a presente pesquisa utilizou-se do método hipotético-dedutivo e a metodologia pautada na técnica de revisão bibliográfica, no qual se utilizará de artigos, livros, 
dissertações, em versões físicas ou eletrônicas, contidas em revistas jurídicas ou plataformas de bancos de dados, como Google Acadêmico, Scielo, Ebsco e Plataforma de Dissertações e Teses da CAPES, e a própria legislação, como base para os debates propostos no presente artigo. Destaca-se que os principais termos pesquisados para o desenvolvimento da pesquisa foram: evolução do divórcio no Brasil; divórcio extrajudicial; divórcio impositivo; direitos da personalidade.

\section{DA EVOLUÇÃO HISTÓRICA DO DIVÓRCIO NO BRASIL}

É certo que o direito, enquanto mecanismo regulador da vida em sociedade, precisa acompanhar a evolução desta pois, do contrário, a sociedade não deixa de avançar e, em contrapartida, fica sem respaldo jurídico que proteja e efetive essa nova realidade social.

Nesta seara, e considerando que o descompasso entre as normas e a dimensão axiológica-social acaba por gerar um direito sem eficácia social, logo, sem respaldo popular, uma vez que o Direito apenas tem sentido enquanto vocacionado a destinar suas normas para uma sociedade que se vê nele refletida (OLIVEIRA, 2006, p. 125), foi-se necessário que ao longo da história, o Direito se adaptasse as mudanças sociais e "é no Direito de Família que se sentem mais facilmente as mudanças sociais e a dificuldade do ordenamento jurídico de, através de seu subsistema normativo, acompanhar e incorporar tais mudanças, adaptando-se à realidade social"' (OLIVEIRA, 2006, p. 120).

Desta forma, até se chegar ao que se conhece como o instituto do divórcio no Brasil na contemporaneidade, muitas foram as discussões e lutas travadas, de forma que a evolução, regulamentação e instituição do mesmo dentro do ordenamento jurídico brasileiro, seja pela via judicial ou administrativa, ocorreram de forma branda e polêmica, principalmente porque o assunto sempre esteve entrelaçado à religião e aos seus dogmas (SILVA; BARUFFI, 2011, p. 435).

No Brasil, do início do século XX, sob a égide do Código Civil de 1916 e de um ordenamento jurídico com forte influência religiosa, o instituto do casamento era indissolúvel e o rompimento ocorria somente no tocante a sociedade conjugal por meio do desquite litigioso ou amigável (SPENGLER; SCHAEFER, 2020, p. 144), todavia permanecia intacto o vínculo conjugal e a obrigação de mútua assistência, cessando apenas os deveres de fidelidade 
e de coabitação sob o mesmo teto e as questões de ordem patrimonial, sem a possibilidade de contrair novo casamento (DIAS, 2021).

Na Constituição de 1934, a indissolubilidade passou a ter caráter constitucional, uma vez que em seu art. 144, "caput”, a mesma previu que "A família, constituída pelo casamento indissolúvel, está sob a proteção especial do Estado", além de ter mantido o instituto do desquite no parágrafo único do aludido artigo. Tal indissolubilidade se manteve nas constituições seguintes $(1937,1946,1967$ e 1969).

Todavia, com a evolução da sociedade, tornou-se necessário a instituição de outras medidas que pudessem solucionar a insatisfação dos cônjuges que não haviam mais interesse na manutenção do vínculo matrimonial (CAETANO; OLIVEIRA, 2020, p. 4), necessitando de um movimento do ordenamento jurídico nesse sentido.

A dissolução do casamento só foi possível, finalmente, com a edição da Emenda Constitucional $n^{\circ}$ 9, de 1977, que admitiu a dissolução do vínculo matrimonial e permitiu o divórcio no Brasil, levando a uma ruptura (necessária) com uma tradição de séculos (SILVA; BARUFFI, 2011, p. 437).

Com a emenda, o $\S 1^{\circ}$ do Art. 175 da Constituição da República Federativa do Brasil de 1967 (já revogada) passou a prever que "o casamento somente poderá ser dissolvido, nos casos expressos em lei, desde que haja prévia separação judicial por mais de três anos" (BRASIL, 1967).

Posteriormente, ainda em 1977, a referida emenda constitucional foi regulamentada por meio da Lei $n^{\circ}$ 6.515/77 (Lei do Divórcio), que extinguiu o instituto do "desquite" e originou o da "separação", bem como tornou o divórcio uma das possibilidades para a dissolução da sociedade conjugal (CAETANO; OLIVEIRA, 2020, p. 4). Para Lôbo (2021), a referida legislação, em solução ao compromisso com os antidivorcistas, manteve o desquite sob a denominação eufemística de separação judicial, como requisito prévio para o divórcio.

Com efeito, a referida lei concedeu a possibilidade de um novo casamento, todavia apenas por uma vez. Apenas com a Constituição de 1988 é que tornou-se permitido divorciar e casar quantas vezes fossem necessárias (SILVA; BARUFFI, 2011, p. 437).

A Constituição de 1988 possibilitou o divórcio, todavia no texto original do art. 226 trouxe limitações no sentido de impor prévia separação judicial por mais de um ano ou se comprovada a separação de fato por mais de dois anos (CAETANO; OLIVEIRA, 2020, p. 5), em que pese tenha avançado no tema em relação a Lei do Divórcio, diminuindo o prazo 
estipulado para a separação de fato de cinco para dois anos e desobrigando a alegação de uma causa de pedir (SPENGLER; SCHAEFER, 2020, p. 144), ou seja, o "único requisito exigido para o divórcio direto passou a ser, assim, a comprovação da separação de fato por mais de dois anos" (SILVA; BARUFFI, 2011, p. 438). Assim, a Constituição avançou, mas não o suficiente.

Posteriormente, o Código Civil Brasileiro de 2002 considerou todo o desenvolvimento social, trazendo expressa previsão da separação e do divórcio (CAETANO; OLIVEIRA, 2020, p. 6), em que pese não tenha trazido grandes avanços para o Direito de Família e apenas trazido uma espécie de compilação das leis já existentes. Destarte, o aludido Código acabou por revogar a Lei do Divórcio no que diz respeito aos aspectos materiais da lei, mas os dispositivos de ordem processual continuaram a vigorar.

Com efeito, a próxima reforma legislativa mais relevante no que se refere ao divórcio adveio com a vigência da Lei n. ${ }^{\circ} 11.441$, de 04 de janeiro de 2007, que passou a possibilitar que qualquer cidadão possa formalizar divórcio, separação, inventário e partilha em Tabelionato de Notas, desde que não haja interesse de incapaz (filho) e a sua realização for consensual (SILVA; BARUFFI, 2011, p. 440), bastando, para tanto, que se dirijam ao Cartório de notas, acompanhados de advogado (CAETANO; OLIVEIRA, 2020, p. 7).

Posteriormente, houve a vigência da Emenda Constitucional no 66 (conhecida como a Emenda do Divórcio), que alterou a redação do art. 226, §6º da Constituição Federal de 1988, passando o mesmo a determinar que "o casamento civil pode ser dissolvido pelo divórcio". Tal emenda, segundo os ensinamentos de Rodrigo da Cunha Pereira (2016), representou o coroamento de uma luta que perdurou por quase dois séculos e que ocorreu em razão do amadurecimento social e jurídico a menor intervenção do Estado na vida privada dos cidadãos.

Assim, apenas com a vigência da referida emenda é que se foi possível a realização do divórcio de forma livre e direta, com a exclusão dos prazos a da prévia necessidade de separação judicial, e que se consolidou a desnecessidade da "existência de culpados pelo rompimento do vínculo conjugal" (SPENGLER; SCHAEFER, 2020, p. 146).

Desta forma, o que se pode verificar ao longo da história brasileira para a consolidação do divórcio, é que se tratou de um processo demasiadamente lento, gradual e realizado em razão da necessidade social de que o ordenamento jurídico respeitasse os avanços sociais e psicológicos que a realidade das famílias e dos indivíduos apontavam, em especial após a 
Constituição Federal de 1988 que consolidou diversas lutas sociais necessárias e que fixou como fundamento da República o princípio da dignidade da pessoa humana e estabeleceu inúmeros direitos e garantias fundamentais, os quais já não coadunavam mais com um direito de família que dificultasse e burocratizasse a dissolução dos vínculos matrimoniais.

\section{DIVÓRCIO EXTRAJUDICIAL: DA SUA PREVISÃO NORMATIVA, IMPORTÂNCIA E CONTORNOS JURÍDICOS AO INSTITUTO DO DIVÓRCIO IMPOSITIVO}

\subsection{PREVISÕES NORMATIVAS DO DIVÓRCIO EXTRAJUDICIAL E IMPORTÂNCIA DO MESMO}

Conforme já destacado anteriormente, o divórcio extrajudicial ingressou no ordenamento jurídico brasileiro por intermédio da Lei n. ${ }^{\circ} 11.441 / 2007$, a qual previu, entre outras coisas, a possibilidade de realização do divórcio pela via extrajudicial, diretamente no Tabelionato de Notas e sem necessidade de homologação judicial, desde que os ex-cônjuges não possuam filhos menores ou incapazes, estejam em consenso sobre os termos do divórcio e estejam acompanhados de advogado(s).

Com efeito, insta destacar que a referida lei teve o condão de acrescentar ao Código de Processo Civil vigente na época (1973) o art. 1124- $\mathrm{A}^{2}$, tendo tal previsão se repetido no Código de Processo Civil de 2015 em seu art. $733^{3}$, com acréscimo apenas da impossibilidade

\footnotetext{
${ }^{2}$ Art. 1.124-A. A separação consensual e o divórcio consensual, não havendo filhos menores ou incapazes do casal e observados os requisitos legais quanto aos prazos, poderão ser realizados por escritura pública, da qual constarão as disposições relativas à descrição e à partilha dos bens comuns e à pensão alimentícia e, ainda, ao acordo quanto à retomada pelo cônjuge de seu nome de solteiro ou à manutenção do nome adotado quando se deu o casamento.

$\S 1{ }^{\circ}$ A escritura não depende de homologação judicial e constitui título hábil para o registro civil e o registro de imóveis.

$\S 2^{\circ} \mathrm{O}$ tabelião somente lavrará a escritura se os contratantes estiverem assistidos por advogado comum ou advogados de cada um deles ou por defensor público, cuja qualificação e assinatura constarão do ato notarial. $\S 3{ }^{\circ}$ A escritura e demais atos notariais serão gratuitos àqueles que se declararem pobres sob as penas da lei.

${ }^{3}$ Art. 733. O divórcio consensual, a separação consensual e a extinção consensual de união estável, não havendo nascituro ou filhos incapazes e observados os requisitos legais, poderão ser realizados por escritura pública, da qual constarão as disposições de que trata o art. 731.

$\S 1^{\circ} \mathrm{A}$ escritura não depende de homologação judicial e constitui título hábil para qualquer ato de registro, bem como para levantamento de importância depositada em instituições financeiras.
} 
de divórcio extrajudicial também quando houver nascituros, bem como excluindo os requisitos legais quanto aos prazos que havia na referida lei.

A lei supracitada possibilitou uma maior agilidade na efetivação do divórcio, haja vista que o divórcio judicial é evidentemente mais moroso em razão da grande demanda do Poder Judiciário, além de ter possibilitado que ambas as partes possam conduzir suas próprias vidas e não mais aguardar meses ou anos pelo divórcio, pois na via extrajudicial o mesmo pode ser resolvido em algumas horas (CAETANO; OLIVEIRA, 2020, p. 7).

Desta forma, o divórcio extrajudicial amplia as possibilidades dos cônjuges, dandolhes liberdade, facilidade e agilidade na dissolução da união, sem ter que aguardar longas esperas no judiciário para, enfim, ter o vínculo matrimonial dissolvido e poderem seguir suas vidas, privilegiando a autonomia privada dos indivíduos para decidirem os rumos da vida que desejam tomar.

Assim, conforme defende Chaves e Rezende (2010, p. 299-300), “o grande mérito da Lei $n^{\circ} 11.441 / 2007$ reside no fato de que seu espírito visa o bem do cidadão, colocando-o acima de qualquer outro interesse. Por meio de um procedimento rápido, eficiente e de menor custo, desobstrui o Poder Judiciário", até porque, conforme defende Cappelletti e Bryant (1988, p. 12), "os juristas precisam, agora, reconhecer que as técnicas processuais servem a funções essenciais; que as cortes não são a única forma de solução de conflitos”.

Nesse contexto, necessário destacar que na contemporaneidadade verifica-se um movimento legislativo no sentido de desjudicialização perante as serventias notariais e registrais (SILVA, 2019, p. 17), o qual se refere a um processo de transferência para os cartórios extrajudiciais de serviços que estão na esfera da justiça, visando simplificar processos e agilizar ações que não envolvem litígio (EL DEBS, 2018).

O termo desjudicialização:

é um neologismo e significa a retirada ou diminuição de causas e atribuições da esfera de ação do Judiciário, sem prejudicar o princípio constitucional do livre acesso do cidadão a esse poder para a efetivação de seus direitos subjetivos. Além dos modos alternativos de solução de litígios tal objetivo pode ser obtido por meio da transferência de competência dos juízos para outros profissionais. (LOUREIRO, 2017)

$\S 2^{\circ} \mathrm{O}$ tabelião somente lavrará a escritura se os interessados estiverem assistidos por advogado ou por defensor público, cuja qualificação e assinatura constarão do ato notarial. 
Assim, nesse movimento de desjudicialização, as serventias notariais e registrais exercem importante papel, pois viabilizam a realização de procedimentos na via extrajudicial, de forma muito mais rápida e menos burocrática, em substituição à efetivação dos mesmos tão somente pela via judicial, que é notadamente mais lenta e burocratizada.

Desta forma, conforme defende Olívia Queiroz (2010), o ordenamento jurídico, ao oferecer ao cidadão possibilidade de valer-se de mecanismo extrajudicial para solucionar seu conflito, de forma democrática e desburocratizada, o Estado acaba por assegurar o amplo acesso à justiça e a promover a cultura de pacificação social.

Sobre o tema, Siqueira, Rocha e Silva (2018, p. 311) defende:

É por meio da desjudicialização que muitos serviços até então atribuídos meramente ao Judiciário podem ser deslocados, seguramente, para o âmbito das serventias extrajudiciais, as quais, qualificadas, modernizadas e adequadas, têm condições de prestar serviço probo e atender as partes com eficiência e celeridade, dotando as relações privadas de segurança jurídica, com alta qualidade e eficácia, num cenário mais eficiente e menos burocrata. São elas integramente hábeis para manejar as técnicas de administração do direito e da justiça com o auxílio e atuação direta dos indivíduos, em prol de toda a sociedade.

Neste interím, não só a previsão do divórcio extrajudicial acaba por ser de suma importância ao assegurar rapidez, facilidade e segurança na dissolução dos vínculos matrimoniais, mas também todo o movimento de desjudicialização, que transfere demandas e procedimentos que anteriormente poderiam ocorrer só pela via judicial para o lócus dos tabelionatos e cartórios de registro, faz-se essencial para o desafogamento do Poder Judiciário, para a ampliação do acesso à justiça e para a promoção de uma cultura de resolução dos conflitos de forma pacífica e consensual, demonstrando, assim, a importância da ampliação de previsões legislativas que permitam essa expansão e valorização da via extrajudicial, além da eficiência dos cartórios para administrar essas demandas desjudicializadas.

\subsection{DIVÓRCIO IMPOSITIVO: CONTORNOS JURÍDICOS}

No Brasil, a única possibilidade de divórcio extrajudicial ainda existente é a anteriormente citada, contida no art. 733 do Código de Processo Civil de 2015, no qual ambos os cônjuges têm consenso quanto ao divórcio e a seus termos e não possuem filhos menores, 
incapazes ou nascituros, todavia encontra-se em discussão no Poder Legislativo uma proposta de nova modalidade de divórcio extrajudicial, qual seja, o divórcio impositivo.

O divórcio impositivo figura como uma alternativa ao divórcio litigioso, uma vez que por meio da aludida modalidade de divórcio, a parte interessada poderia realizar a dissolução da sociedade conjugal por meio de averbação no Cartório de Registro Civil em que procedeuse o casamento, finalizando o divórcio no Cartório em questão e sem precisar valer-se da via judicial ou da própria via extrajudicial bilateral (SOUZA, 2020, p. 51).

Sobre a caracterização do divórcio impositivo ainda, preleciona Luiza Almeida (2020, p. 1) que o mesmo "é o divórcio requerido unilateralmente, ou seja, por apenas um dos cônjuges, direto no cartório, sem a necessidade de acesso ao judiciário", isto é, trata-se de modalidade de divórcio que permite que um dos cônjuges, unilateralmente, requeira a dissolução do vínculo matrimonial, mediante averbação no Cartório de Registro Civil em que se realizou o casamento, sem a necessidade de anuência do outro cônjuge quanto ao divórcio.

O divórcio impositivo adentrou no ordenamento jurídico por meio do Provimento $\mathrm{n}^{\mathrm{o}}$ 06/2019, da Corregedoria Geral da Justiça do Tribunal de Justiça de Pernambuco, que permitia a dissolução do vínculo conjugal do casamento, de forma unilateral, no Cartório de Registro Civil em que se deu o casamento (ARAÚJO; SIQUEIRA, 2020, p. 15).

O referido provimento considerou para a instituição do "divórcio impositivo", entre outras coisas, a necessidade de medidas desburocratizantes ao registro civil nos casos do divórcio, por se tratar tal instituto, desde a Emenda Constitucional $n^{\circ}$ 66/2010, de direito potestativo de cada um dos cônjuges, bem como na autonomia da vontade que se insere no princípio da autonomia privada em sua dimensão civil-constitucional (PERNAMBUCO, 2019, p. 1), e determinou, então, a indicação de que:

Art. $1^{\circ}$. [...] qualquer dos cônjuges poderá requerer, perante o Registro Civil, em cartório onde lançado o assento do seu casamento, a averbação do seu divórcio, à margem do respectivo assento, tomando-se o pedido como simples exercício de um direito potestativo do requerente. (PERNAMBUCO, 2019, p. 2)

O provimento destacava ainda, em seu art. $2^{\circ}$, que "o requerimento independe da presença ou da anuência do outro cônjuge, cabendo-lhe unicamente ser notificado, para fins de prévio conhecimento da averbação pretendida [...]" (PERNAMBUCO, 2019, p. 2), ou seja, 
o divórcio impositivo seria uma modalidade de divórcio extrajudicial em que independe, até mesmo, da anuência do outro cônjuge com relação ao divórcio.

Todavia, diante das críticas feitas ao provimento, o Conselho Nacional de Justiça, através do ministro Humberto Martins, determinou a revogação do aludido provimento, mediante Recomendação no 36/2019, que assim dispôs:

Art. $1^{\circ}$ Recomendar aos Tribunais de Justiça dos Estados e do Distrito Federal que: I - se abstenham de editar atos regulamentando a averbação de divórcio extrajudicial por declaração unilateral emanada de um dos cônjuges (divórcio impositivo), salvo nas hipóteses de divórcio consensual, separação consensual e extinção de união estável, previstas no art. 733 do Código de Processo Civil.

II - havendo a edição de atos em sentido contrário ao disposto no inciso anterior, providenciem a sua imediata revogação. (CONSELHO NACIONAL DE JUSTIÇA, 2019)

Entre as justificativas apresentadas pelo ministro para revogar o provimento, encontrase a questão de competência privativa da União para legislar, entre outras matérias, sobre direito civil e processo civil, bem como o argumento de que as hipóteses de divórcio extrajudicial são apenas as que já se encontram prescritas em lei, sem a possibilidade de criar outras modalidades sem amparo legal (CONSELHO NACIONAL DE JUSTIÇA, 2019), ou seja, nova modalidade de divórcio somente poderia ser criada por meio de legislação nacional, proposta por alguns dos legitimados da União e após aprovada seguindo todos os trâmites legais exigidos para a aprovação e vigência de Lei Federal, não podendo ser objeto de qualquer órgão de nível Estadual.

Nesse cenário, posteriormente a suspensão do provimento estadual que previa o divórcio impositivo, o Senador Rodrigo Pacheco propôs novo projeto de lei (PLS 3.457/2019), abordando essa forma de divórcio impositivo em formato de legislação federal (ARAUJO; SIQUEIRA, 2020, p. 15). O referido projeto de Lei, que tramita no Senado Federal e já foi aprovada na Comissão de Constituição e Justiça, visa acrescentar ao Código de Processo Civil o art. 733-A, permitindo que um dos cônjuges requeira a averbação de divórcio no cartório de registro civil ainda que o outro cônjuge não concorde com a separação (SENADO FEDERAL, 2019).

O art.733-A que o projeto visa inserir no Código de Processo Civil, conforme texto inicial do projeto, assim disporia: 
Art. 733-A. Na falta de anuência de um dos cônjuges, poderá o outro requerer a averbação do divórcio no Cartório do Registro Civil em que lançado o assento de casamento, quando não houver nascituro ou filhos incapazes e observados os demais requisitos legais.

$\S 1^{\circ}$. O pedido de averbação será subscrito pelo interessado e por advogado ou defensor público, cuja qualificação e assinatura constarão do ato notarial.

$\S 2^{\circ}$. O cônjuge não anuente será notificado pessoalmente, para fins de prévio conhecimento da averbação pretendida. Na hipótese de não encontrado o cônjuge notificando, proceder-se-á com a sua notificação editalícia, após insuficientes as buscas de endereço nas bases de dados disponibilizadas ao sistema judiciário.

$\S 3^{\circ}$. Após efetivada a notificação pessoal ou por edital, o Oficial do Registro Civil procederá, em cinco dias, à averbação do divórcio.

$\S 4^{\circ}$. Em havendo no pedido de averbação do divórcio, cláusula relativa à alteração do nome do cônjuge requerente, em retomada do uso do seu nome de solteiro, o Oficial de Registro que averbar o ato, também anotará a alteração no respectivo assento de nascimento, se de sua unidade; ou, se de outra, comunicará ao Oficial competente para a necessária anotação.

$\S 5^{\circ}$. Com exceção do disposto no parágrafo anterior, nenhuma outra pretensão poderá ser cumulada ao pedido de divórcio, especialmente alimentos, arrolamento e partilha de bens ou medidas protetivas, as quais serão tratadas no juízo competente, sem prejuízo da averbação do divórcio. (SENADO FEDERAL, 2019)

Assim, conforme se verifica no citado artigo, o mesmo, se aprovado o projeto de lei, possibilitará que na falta de anuência de um dos cônjuges quanto ao divórcio, o outro possa requerer a dissolução do vínculo matrimonial por meio de averbação do divórcio no Cartório de Registro Civil, quando inexistir na relação nascituro ou filhos incapazes, de cujo pedido de averbação o cônjuge não anuente será, em regra, notificado pessoalmente e, 5 (cinco) dias após a notificação, se efetivará a averbação. Vale destacar que o divórcio impositivo, pelo que prevê o projeto de lei, se prestará tão somente para dissolver o vínculo matrimonial e, se o cônjuge requerente desejar, a alteração do nome para o de solteiro, sem a possibilidade de cumulação de nenhuma outra pretensão como alimentos, partilhas de bens e etc., que deverão ser tratadas no juízo competente.

O referido projeto ainda está sendo alvo de debates e será foco de votação no Senado Federal, não tendo adentrado, de fato, ao ordenamento jurídico brasileiro, e o qual origina diversos debates acerca de sua validade jurídica e utilidade prática, uma vez que pode ser compreendida como uma forma de divórcio litigioso que poderia ser realizada em cartório, acompanhado obrigatoriamente de advogado, que romperia com o vínculo matrimonial, mas deixaria de lado controvérsias que normalmente se discutem em divórcios, como partilha de bens e alimentos, de modo que a sua aprovação ainda depende, além dos requisitos procedimentais, de debates jurídicos de diversas ordens, como se tal modalidade violaria outras normas legais, se estaria amparada constitucionalmente pelas garantias fundamentais e 
pelo direito potestativo ao divórcio ou, ainda, se o seu ingresso no ordenamento jurídico traria benefícios justificáveis em face de malefícios que podem advir dele.

Nesse sentido, consideramos que, em que pese ainda se figure como um instrumento que não adentrou ao ordenamento jurídico brasileiro efetivamente, os debates prévios sobre o mesmo se fazem fundamental, até como forma de aferir a viabilidade ou não do seu ingresso efetivo na legislação brasileira, em especial quando considerada a esfera protetiva dos direitos da personalidade, que guardam íntima ligação com o princípio da dignidade da pessoa humana, fundamento da República Federativa do Brasil.

\section{DIVÓRCIO IMPOSITIVO E A PROTEÇÃO DOS DIREITOS DA PERSONALIDADE: UMA ANÁLISE À LUZ DA AUTONOMIA DA VONTADE E DO DIREITO À LIBERDADE AFETIVA}

A Constituição Brasileira de 1988 foi um marco na tutela de direitos aos cidadãos, em especial por ter situado o princípio da dignidade da pessoa humana como fundamento da República Federativa do Brasil (art. 1º, III, CF/88) e por ter resguardado um extenso rol de direitos e garantias fundamentais que devem ser efetivados à todos, sem distinção de qualquer natureza.

No ordenamento jurídico brasileiro, o princípio da dignidade da pessoa humana se mostra como o princípio dos princípios, isto é, é o princípio que deve servir de parâmetro para todos os demais (MORAES, 2019, p. 19) e, em que pese o mesmo não possua uma conceituação fixa, acaba sempre por evidenciar o respeito ao ser humano (MORAES, 2019, p. 21) e cujo conteúdo não é absoluto, pois a dignidade da pessoa humana é fruto de determinado momento da história, do Estado e da sociedade (VAZ; REIS, 2007, p. 191).

Contemporaneamente, na construção moderna de dignidade da pessoa humana, os pensamentos de Immanuel Kant têm importância precípua. Em seu pensamento, o teórico defende que o homem existe como um fim em si mesmo e não como um meio à disposição desta ou daquela vontade (KANT, 2009, p. 239-240), pois para Kant, as coisas são passíveis de substituição na medida em que possuem um preço, já o homem possui dignidade, valor este que se coloca acima de todo o preço ${ }^{4}$.

\footnotetext{
${ }^{4}$ KANT, 2005, p. 77-78: “[...] no reino dos fins tudo tem ou um preço ou uma dignidade . Quando uma coisa tem um preço, pode pôr-se em vez dela qualquer coisa equivalente; mas quando uma coisa está acima de todo o
} 
Os direitos da personalidade, por sua vez, têm proteção de ordem constitucional através do princípio da dignidade da pessoa humana, que vigora como "uma cláusula geral de concreção da proteção e do desenvolvimento da personalidade do indivíduo" (SZANIAWSKI, 2005, p. 137), na medida em que são direitos sem os quais a personalidade restaria completamente irrealizada e sem valor concreto, direitos sem os quais todos os outros direitos subjetivos sequer teriam interesse para os indivíduos, isto é, são direitos que, se inexistentes, a pessoa não existiria como tal (CUPIS, 2004, p. 24).

Tratam-se de direitos que se fazem necessários para a compreensão de pessoa, uma vez que se referem a um conjunto de bens tão particulares do ser humano que acabam por se confundir com o próprio sujeito, constituindo manifestações da sua própria personalidade (BELTRÃO, 2005, p. 24) e estão atrelados à concepção de proteção da pessoa no aspecto que lhe é mais íntimo, isto é, no seu livre desenvolvimento enquanto ser (CANTALI, 2009, p. 69).

Ademais, defende Roxana Borges (2007, P. 127) que:

[...] os direitos de personalidade podem ser exercidos também na esfera da autonomia privada da pessoa. Vistos assim, os direitos de personalidade não são deveres da pessoa, como parte da doutrina concebe, mas liberdade de viver, de forma autônoma, os aspectos mais íntimos, mais próprios, mais personalíssimos de sua vida, podendo, inclusive, utilizar-se do negócio jurídico para obter a satisfação de seus interesses.

Assim, uma das esferas de proteção dos direitos da personalidade - talvez a mais importante - se dá sobre o direito à liberdade e a autodeterminação das pessoas, liberdade para viver, liberdade de pensar, liberdade para escolher quem quer que esteja ou não em sua vida, isto é, liberdade para escolher os ditames da sua vida em qualquer aspecto que seja.

Sobre esse aspecto, Elpídio Paiva (2020, p. 17) ensina que:

Afirmar a importância da proteção da liberdade do titular dos direitos da personalidade para garantir os seus direitos, de modo a permitir sua livre autodeterminação como máxima da dignidade humana, só pode ser alcançado com a tutela do livre exercício dos direitos da personalidade.

preço, e portanto não permite equivalente, então tem ela dignidade[...] Esta apreciação dá pois a conhecer como dignidade o valor de tal disposição de espírito e põe-na infinitamente acima de todo preço. Nunca ela poderia ser posta em cálculo ou confronto com qualquer coisa que tivesse um preço, sem de qualquer modo ferir sua santidade". 
Assim, tutelar os direitos da personalidade e o livre desenvolvimento da personalidade da pessoa é tutelar, entre outras coisas, o direito à liberdade, a autodeterminação e a autonomia da vontade dos mesmos, o que inclui a liberdade afetiva dos indivíduos de escolher com quem quer se relacionar, com quem quer casar e, ainda, quando quer optar pelo divórcio e seguir a vida sem o ex-cônjuge.

Nesta seara, e diante da importância já exercida pelas serventias notariais e registrais e eficácia na administração de demandas antes possíveis só judicialmente, tem-se que as mesmas vigoram como um valioso instrumento de proteção e efetivação dos direitos da personalidade, "principalmente por respeitarem a autonomia dos indivíduos, bem como pela maior celeridade e efetividade de seus procederes, os quais, com segurança e autenticidade, fornecem o trato adequado e satisfatório dos conflitos"(SIQUEIRA; ROCHA; SILVA, 2018, p. 317), revelando-se a necessidade imperativa da adoção destas novas vias realizadoras de direitos, garantias e pretensões dos indivíduos, de modo hajam respostas adequadas e eficazes, gerando, assim, o devido respeito e concretização da pessoa humana como tal (SIQUEIRA; ROCHA; SILVA, 2018, p. 330).

Assim sendo, e considerando a importância de considerar o respeito aos direitos da personalidade dos indivíduos, entre os quais a liberdade e a autodeterminação que decorre da autonomia da vontade estão incluídas na proteção central do livre desenvolvimento da personalidade, pode-se considerar que o divórcio impositivo teria papel precípuo no próprio respeito a essa liberdade, no caso, à liberdade afetiva, ao viabilizar e facilitar uma rápida e eficaz dissolução do vínculo matrimonial, mesmo nos casos em que o outro cônjuge não concorde com o divórcio, uma vez que ninguém deve ser obrigado a permanecer em um casamento que não mais deseja, nem a se permanecer conectado pelo vínculo matrimonial com outra pessoa que não mais satisfaz as suas pretensões de vida.

Por fim, reconhecer a validade do ingresso do divórcio impositivo no ordenamento jurídico brasileiro é uma forma de tutelar, em essência, o direito à liberdade afetiva e a autodeterminação de cada indivíduo, tutelando, assim, seus direitos da personalidade, inclusive no que se refere aos aspectos psíquicos da pessoa, haja vista que processos demasiadamente longos e burocráticos, especialmente quando se versa sobre divórcios litigiosos em que o(a) cônjuge não requerente discorda com a decisão de rompimento do vínculo matrimonial do(a) cônjuge requerente, normalmente produz-se efeitos trágicos no psicológico do cônjuge que só pretende, enfim, colocar fim a um casamento que não mais 
deseja manter, de forma que o divórcio impositivo se colocaria não apenas como um instrumento que não viola os direitos da personalidade dos indivíduos, mas sim como um instrumento que tem o potencial inverso, isto é, de tutelar a proteção desses direitos, até porque, ao efetivar apenas o rompimento do vínculo matrimonial e a alteração do nome do(a) cônjuge requerente, se ele(a) assim desejar, não prejudicará quaisquer direitos do outro cônjuge, como direito à alimentos e partilha de bens, que deverá ocorrer na via judicial.

\section{CONSIDERAÇÕES FINAIS}

Inicialmente, a presente pesquisa verificou que o divórcio, instituto tão importante da sociedade contemporânea, somente se instalou de forma livre no ordenamento jurídico brasileiro após décadas de resistência legislativa em se reconhecer a necessidade de um instrumento que fosse, de fato, efetivo na dissolução do casamento, isto é, que findasse não somente os deveres conjugais mas também que dissolvesse de vez o vínculo matrimonial, permitindo aos ex-cônjuges que seguissem suas vidas e casassem quantas vezes desejassem.

O divórcio, em 2007, por intermédio da Lei $\mathrm{n}^{\mathrm{o}}$ 11.441/2007, também passou a ser possível na via extrajudicial, podendo os ex-cônjuges proceder o divórcio por meio de escritura pública em Tabelionato de Notas, desde que não possuam filhos menores ou incapazes, tenha consenso e estejam acompanhados por advogado(s), servindo-se como um instrumento de suma importância, ao agilizar e desburocratizar o processo de divórcio, diferentemente de quando ocorre pela via judicial e, contribuindo, inclusive, para o surgimento de um movimento de desjudicialização, isto é, que busca levar para a via extrajudicial demandas que anteriormente só eram possíveis por meio de ação judicial, notadamente burocratizada e demorada em razão de formalidades mais rígidas.

E é nesta toada de desjudicialização, somada com a importância exercida pelo divórcio extrajudicial e com a defesa de que o divórcio vigoraria como um direito potestativo do cônjuge requerente, que o divórcio impositivo passou a ser proposto no Brasil, inicialmente por meio de um provimento estadual e contemporaneamente por meio de projeto de lei que tramita perante o Senado Federal.

O divórcio impositivo teria, assim, por intuito permitir que o cônjuge com interesse na dissolução do vínculo matrimonial pudesse, de forma unilateral e independente de concordância do outro cônjuge, requerer o divórcio no Cartório de Registro Civil em que se 
procedeu o casamento, pedido este que se efetivaria após a notificação do cônjuge não requerente, dissolvendo o vínculo matrimonial de ambos.

Tal divórcio, em uma analise à luz dos direitos da personalidade, em que se protege especialmente o livre desenvolvimento da personalidade da pessoa, teria um importante papel no respeito ao direito à liberdade e a autodeterminação que deriva da autonomia privada, protegendo e efetivando de forma ágil e eficaz a dissolução do vínculo matrimonial, mesmo que o cônjuge não requerente discorde do divórcio, pois ninguém deve ser privado do direito de dissolver um casamento que não mais deseja permanecer, no mesmo.

Desta forma, o divórcio impositivo poderia vigorar como um meio de tutelar o direito à liberdade afetiva e a autodeterminação de cada indivíduo, bem como funcionar como um meio de proteção dos aspectos psíquicos do cônjuge requerente, ao atribuir agilidade no processo de dissolução do vínculo matrimonial que, por vezes, é tão doloroso.

Por fim, vale destacar que o fato do divórcio impositivo dissolver o vínculo matrimonial não acarreta em prejuízo aos direitos do(a) cônjuge não requerente, uma vez que todas as demais demandas atinente ao processo de divórcio, como pedido de alimentos e partilha de bens, deverão ser feitas pela via judicial, tornando essa modalidade de divórcio viável e potencialmente importante no contexto jurídico brasileiro.

\section{REFERÊNCIAS}

ALMEIDA, Luiza. Divórcio impositivo: o que é e quais os procedimentos. 2020.

ARAUJO, Litiane Motta Marins; SIQUEIRA, Bárbara Márcia Nascimento dos Santos. Divórcio unilateral extrajudicial. Revista Acadêmica de Direito da UNIGRANRIO, v. 10, n.1, p. 1-23, 2020. Disponível em: http://publicacoes.unigranrio.edu.br/index.php/rdugr/article/view/6310/3152. Acesso em: 25.06.2021.

BELTRÃO, Sílvio Romero. Direitos da personalidade. São Paulo: Atlas, 2005. 
BORGES, Roxana Cardoso Brasileiro. Direitos da personalidade e autonomia privada. 2.ed. São Paulo: Saraiva, 2007.

BRASIL. Constituição da República Federativa do Brasil de 1967. Revogada. Disponível em:

http://www.planalto.gov.br/ccivil_03/constituicao/Constituicao67EMC69.htm\#art175\%C2\% A71. Acesso em: 21.06.2021.

CAETANO, Leidiane Moreira Silveira; OLIVEIRA, Victor Henrique Fernandes e. Divórcio extrajudicial: inovações trazidas pela Lei $\mathrm{n}^{\mathrm{o}}$ 11.441/2007 e o conhecimento da população no município de Metrinchã-GO acerca de suas possibilidades. Revista de Estudos Interdisciplinares do Vale do Araguaia-REIVA, v. 3, n. 02, p. 1-16, 2020. Disponível em: http://reiva.emnuvens.com.br/reiva/article/view/127/106. Acesso em: 22.06.2021.

CANTALI, Fernanda Borghetti. Direitos da personalidade: disponibilidade relativa, autonomia privada e dignidade humana. Porto Alegre: Livraria do Advogado Editora, 2009.

CAPPELLETTI, Mauro; GARTH, Bryant. Acesso à Justiça. Tradução de Ellen Gracie North Fleet. Porto Alegre: Fabris, 1988.

CHAVES, Carlos Fernando Brasil; REZENDE, Afonso Celso F. Tabelionado de notas e o notário perfeito. 6.ed. Campinas, SP: Millennium Editora, 2010.

CONSELHO NACIONAL DE JUSTIÇA - CNJ. Recomendação $\mathbf{n}^{\mathbf{0}} \mathbf{3 6}$, de 30 de maio de 2019. Disponível em: https://atos.cnj.jus.br/atos/detalhar/2923. Acesso em: 25.06.2021.

CUPIS, Adriano de. Os direitos da personalidade. Campinas- SP: Romana Jurídica, 2004.

DIAS, Maria Berenice. Manual de direito das famílias [livro eletrônico]. 14.ed. São Paulo: Jus Podivm, 2021.

EL DEBS, Martha. Legislação Notarial e de Registros Públicos Comentadas. Salvador: JusPodivm, 2018.

KANT, Immanuel. Fundamentação da metafísica dos costumes (1785). Tradução Paulo Quintela. Lisboa: Edições 70, 2005.

KANT, Immanuel. Fundamentação da metafísica dos costumes. Trad. Nova com introdução de notas por Gomemuido Antônio de Almeida. São Paulo: Discurso Editorial: Barcarolla, 2009.

LÔBO, Paulo. Direito civil: famílias. 11.ed. São Paulo: Saraiva, 2021.

LOUREIRO, Luiz Guilherme. Registros Públicos: teoria e prática. Salvador: Juspodivm, 2017. 
LUZ SEGUNDO, Elpídio Paiva. Direitos da personalidade: quo vadis? Revista de Direito da Faculdade Guanambi, v.7, n.01, e280, p. 1-21, jan./jun. 2020. Disponível em: http://revistas.faculdadeguanambi.edu.br/index.php/Revistadedireito/article/view/280/167.

Acesso em: 27.06.2021.

MEDINA, José Miguel Garcia. Constituição Federal Comentada com Jurisprudência selecionada do STF e de outros Tribunais. São Paulo: Revista dos Tribunais, 2021.

MORAES, Carlos Alexandre. Responsabilidade civil dos pais na reprodução humana assistida. 1.ed. São Paulo: Método, 2019.

NEGRÃO, Theotonio et al. Código de Processo Civil e Legislação Processual em Vigor. 52.ed. São Paulo: Saraiva, 2021.

OLIVEIRA, José Sebastião. A família e as Constituições Brasileiras no contexto dos direitos fundamentais e da personalidade. Revista Jurídica Cesumar, v. 6, n. 1, p. 75-148, 2006. Disponível

em: https://periodicos.unicesumar.edu.br/index.php/revjuridica/article/view/309/168. Acesso em 15.06.2021.

PEREIRA, Rodrigo da Cunha. Divórcio: teoria e prática. 5.ed. São Paulo, 2016.

PERNAMBUCO. Corregedoria Geral de Justiça. Provimento $n^{\circ}$ 06, de 29 de abril de 2019. Regulamenta o procedimento de averbação, nos serviços de registro civil de casamentos, do que se denomina de "divórcio impositivo e que se caracteriza por ato de autonomia de vontade de um dos cônjuges, em pleno exercício do seu direito potestativo, no âmbito do Estado de Pernambuco, e dá outras providências. Disponível em: https://www.tjpe.jus.br/documents/29010/2103503/PROVIMENTO+N\%C2\%BA+06-2019CGJ+ORIGINAL.pdf/80b8a35e-9a57-90c0-c536-9b72037741b2. Acesso em: 25.06.2021.

QUEIROZ, Olívia Pinto de Oliveira Bayas. SEPARAÇÃO E DIVÓRCIO EXTRAJUDICIAIS-COMENTÁRIOS À LEI 11.441/2007. Anais do XIX Encontro Nacional do CONPEDI realizado em Fortaleza-CE. 2010. Disponível em: http://www.publicadireito.com.br/conpedi/manaus/arquivos/anais/fortaleza/4135.pdf. Acesso em: 24.06.2021.

SENADO FEDERAL. Projeto de Lei $\mathbf{n}^{\mathbf{0}}$ 3.457, de 2019. Disponível em: https://www25.senado.leg.br/web/atividade/materias/-/materia/137242. Acesso em: 25.06.2021.

SENADO FEDERAL. Texto inicial do Projeto de Lei $\mathbf{n}^{\mathbf{0}}$ 3.457, de 2019. Disponível em: https://legis.senado.leg.br/sdleg-

getter/documento?dm=7964616\&ts=1594034956865\&disposition=inline. Acesso em: 25.06.2021.

SILVA, Débora dos Santos; BARUFFI, Helder. Casamento e divórcio: algumas reflexões em torno da emenda constitucional n ${ }^{\circ}$ 66/2010. Revista Jurídica Cesumar - Mestrado, v. 11, n. 2, p. 433-450, jul./dez. 2011. Disponível em: 
https://periodicos.unicesumar.edu.br/index.php/revjuridica/article/view/2010/1414. Acesso em 15.06.2021.

SILVA, Rafael Azanha. Acesso à justiça e divórcio consensual sem menores ou incapazes: análise de dados sobre a (des) judicialização no Foro do Norte da Ilha da Comarca da Capital/SC (2014-2018) [dissertação]. Dissertação (Mestrado profissional) - Universidade Federal de Santa Catarina, Centro de Ciências Jurídicas, Programa de Pós-graduação em Direito. $\quad 76$ p. $\quad$ Florianópolis, 2019. Disponível em: https://repositorio.ufsc.br/bitstream/handle/123456789/215360/PDPC-P0042-

D.pdf?sequence=-1\&isAllowed=y. Acesso em: 24.06.2021.

SIQUEIRA, Dirceu Pereira; ROCHA, Maria Luiza de Souza; SILVA, Rodrigo Ichikawa Claro. Atividades notariais e registrais, judicialização e acesso à justiça: o impacto da desjudicialização para a concretização dos direitos da personalidade. Revista Jurídica Cesumar, v. 18, n. 1, p. 305-334, jan./abril 2018. Disponível em: https://periodicos.unicesumar.edu.br/index.php/revjuridica/article/view/5701/3193. Acesso em: 27.06.2021.

SOUZA, João Pedro Ferraz de. Divórcio impositivo. Monografia - Curso de Graduação em Direito da Universidade do Sul de Santa Cantarina. 68 p. 2020. Disponível em: https://www.riuni.unisul.br/handle/12345/11106. Acesso em: 25.06.2021.

SPENGLER, Fabiana Marion; SCHAEFER, Rafaela Matos Peixoto. Divórcio: Evolução histórica e legislativa com destaque às inovações do Código de Processo Civil. Revista da Faculdade de Direito da UERJ - Rio de Janeiro, n.37, p. 142-164, jun. 2020, p. Disponível em: https://www.e-publicacoes.uerj.br/index.php/rfduerj/article/view/42356/34527. Acesso em: 18 jun. 2021.

SZANIAWSKI, Elimar. Direitos da personalidade e sua tutela. 2.ed. rev., atual. e ampl. São Paulo: Editora Revista dos Tribunais, 2005.

VAZ, Wanderson Lago; REIS, Cleyton. Dignidade da pessoa humana. Revista Jurídica Cesumar. v. 7, n. 1, p. 181-196, jan./jun. 2007. Disponível em: https://periodicos.unicesumar.edu.br/index.php/revjuridica/article/view/522/380. Acesso em: 25.06.2021. 